\title{
Long Term Metabolic and Health Effects of a Low-Carbohydrate, High-Fat, High-Protein Diet in Mus musculus: A Nineteen Week Longitudinal Study
}

\author{
Donald Harris, Christopher Bell, Misty Retzlaff, \\ Stephanie Toering, Elizabeth Wurdak, and David Mitchell \\ College of St. Benedict and St. Johns University \\ Collegeville, Minnesota 56321 USA
}

Received:February 4, $2005 \quad$ Accepted: April 1, 2005

\begin{abstract}
This study was designed to investigate the long-term metabolic adaptations and health effects of a low-carbohydrate, high-fat/protein diet in mice. One-month-old male ICR mice were fed a control, conventional high-carbohydrate diet $(n=21)$ or an experimental low-carbohydrate, highfat, high-protein diet $(n=20)$. One pair of mice per group was euthanized at two-week intervals for five months for tissue analysis. Basic metabolic data, body and tissue weights, blood and plasma metabolite and lipid profiles, liver glycogen and protein content, and liver serine dehydratase and glucose-6-phosphate dehydrogenase activities were analyzed. The low-carbohydrate group gained significantly more weight ( $p<0.005$ after 4 weeks) than the normally growing control group. Although ketosis was initially stimulated in the low-carbohydrate group, enzyme and tissue analysis suggest that gluconeogenic activity was sufficient to alleviate the effects of severe dietary carbohydrate restriction and allow for glucose metabolism close to that demonstrated in the control group.
\end{abstract}

\section{INTRODUCTION}

Obesity is a major, and growing, international public health concern. The 1999-2002 National Health and Nutrition Examination Survey reported that approximately $65 \%$ of American adults are either overweight or obese [1]. The US Centers for Disease Control and Prevention and the World Health Organization have classified obesity as a national and international epidemic, respectively. Obesity is a significant risk factor for numerous disorders, including liver disease, stroke, type II diabetes, cancer, and cardiovascular disease, and is associated with over 400,000 deaths annually in the United States [2-4].

Short term adherence to a lowcarbohydrate, high-fat, high-protein (LC$\mathrm{FP}^{\dagger}$ ) diet, such as the popular Atkins diet

$\dagger$ Abbreviations: BW, body weight; $\mathrm{CHO}$, carbohydrate; G6P, glucose-6-phosphate; (see Table 1 for caloric composition), have been shown to promote short term weight and fat loss, induce favorable changes in serum lipid profiles, and reduce appetite versus conventional, high-carbohydrate diets [5-12]. The Atkins diet is characterized by extreme reduction in carbohydrate $(\mathrm{CHO})$ intake with a compensatory increase in dietary protein and fat intake restricted only by appetite $[7,12,13]$. Deprived of glucose,

G6PDH, glucose-6-phosphate dehydrogenase; BHBT, $\quad \beta$-hydroxybutyrate; $\quad \beta H B T D H, \quad \beta$ hydroxybutyrate dehydrogenase; LC, lowcarbohydrate group or diet; HC, highcarbohydrate/control group or diet; HDL, highdensity lipoprotein cholesterol; LC-HFP, lowcarbohydrate, high-fat, high-protein; LDL, lowdensity lipoprotein cholesterol; PTD, Purina TestDiet; RT, room temperature; $\mathrm{SDH}$, serine dehydratase; TRG, triacylglyceride; TC, total cholesterol; VLDL, very-low-density lipoprotein cholesterol. 
the body induces fatty acid oxidation, leading to a perpetual state of ketosis comparable to that observed during fasting; protein and triacylglycerol catabolism increase to provide energy and substrates to meet metabolic demands [7,12-14]. According to Atkins and others, the macronutrient profile of LC-HFP diets, and the metabolic changes they induce, allow for weight and fat loss without a reduction in total caloric intake $[8,13]$.

Short-term adherence to a LC-HFP diet has been shown to promote favorable health changes. However, the metabolic mechanisms and long term health effects of the diet are still poorly understood $[7,12,15]$. For example, whether weight loss results from water loss, as glycogen stores are depleted, caloric restriction, or from fat loss induced by ketosis is still under contention, as is the efficacy of the diet for healthy, long term weight loss and maintenance $[5,7,11,12,16]$. Likewise, changes in serum lipids may be the result of weight loss rather than the macronutrient profile of the Atkins diet itself [7,12]. Further, the combined long-term effects of a LC-HFP diet on metabolic pathways in mammals have not been thoroughly explored $[12,16]$.

The purpose of this study was to investigate the metabolic adaptations and health effects resulting from long term consumption of a LC-HFP diet in mice. Basic observation included gross weight changes and consumption and excretion patterns. Systemic glucose status and ketosis was assessed by testing blood glucose and plasma $\beta$-hydroxybutyrate ( $\beta H B T)$ levels, respectively. Hepatic analysis included protein and glycogen contents, and enzyme activities; glucose-6phosphate dehydrogenase (G6PDH; EC 1.1.1.49) and serine dehydratase (SDH; EC 4.3.1.17) were analyzed to assess ancillary glucose metabolism, and protein degradation and gluconeogenic activity, respectively. Adipose deposition and blood lipid profiles were used to determine fat metabolism and cardiovascular effects.

\section{EXPERIMENTAL PROCEDURE}

a. General

All chemicals and enzymes were obtained from Sigma-Aldrich (St. Louis,
MO), mice from Harlan Industries Inc. (Indianapolis, MO), and sedatives from Phoenix Pharmaceuticals (St. Joseph, MO). Control and experimental pelleted diets were obtained from Purina Lab/TestDiet (PTD; St. Louis, MO). Assays were performed using Beckmann (Fullerton, CA) DU-50 or 64 spectrophotometers. Metabolic monitoring was performed with Nalgene (Rochester, NY) 650 metabolic cages, and whole blood was analyzed using a Cholestech (Hayward, CA) LDX reader and plates.

Unless otherwise specified, all samples and solutions were prepared with distilled water and were stored and used at $4^{\circ} \mathrm{C}$ or colder. Liver tissue, and plasma and liver extracts were stored at $-80^{\circ} \mathrm{C}$ until later preparation or analysis. For all NADspecies coupled assays, samples were incubated in a room temperature (RT) water bath for 10 minutes before assaying, and $\Delta \mathrm{A}_{340 \mathrm{~nm}}$ was used to calculate the appropriate concentration or activity after accounting for reference and coupling reaction activities; all assays used Beckmann $3.0 \mathrm{~mL}, 1.0 \mathrm{~cm}$ light path quartz cuvettes at RT.

\section{b. Animals}

Forty-two 19 day old male ICR mice were caged in 21 randomly assigned pairs and acclimated to $21 \pm 1^{\circ} \mathrm{C}$ and a 12 hour light/dark cycle. All mice had PTD 5012 chow and municipal water ad libitum. At 32 days old, 10 pairs of mice were each assigned to a control (HC) or test (LC) group, and one pair to a baseline group; an extra, $43^{\text {rd }}$ mouse was assigned to the control group and housed individually. The HC group was continued on PTD 5012, and the LC group was fed a custom PTD LCHFP chow. (Table I) The baseline group was immediately sacrificed and tested. One pair per group was sacrificed and tested one week later, continuing every two weeks subsequently. All surviving paired mice were weighed every seven days throughout the study.

All mice were cared for and treated according to the guidelines of the College of St. Benedict-St. Johns University Institutional Animal Care and Use Committee and the National Academy of Sciences Guide for the Care and Use of Laboratory Animals. 
c. Metabolic Monitoring, Euthanasia, And Tissue Collection

Two weeks before euthanasia, one pair per group was transferred to individual metabolic cages; food and water intake, and fecal and urine output was measured every 3-4 days. Water and respective food was continued ad libitum until sedation. The mice were anesthetized with $80 \mu \mathrm{g}$ Ketamine and $8.0 \mu \mathrm{g}$ Xylazine/g BW diluted in an equal volume of $\mathrm{pH} 7.4$ phosphate buffer, injected through the gluteus maximus; the mouse undergoing sedation and dissection at any given time was isolated from the other mice. The abdomen was incised through the sternum, and blood withdrawn via cardiac puncture. The mice were immediately euthanized with $1 \mathrm{~mL}$ saturated $\mathrm{KCl}$ delivered to the heart. The liver and subcutaneous abdominal fat deposits were extracted and weighed; the former tissue was flash frozen in liquid nitrogen.

\section{d. Tissue Preparation And Analysis}

i. Whole Blood and Plasma. After extraction, the whole blood was heparinized and $35.0 \mu \mathrm{L}$ withdrawn for lipid and glucose analysis. Plasma was prepared from centrifugation of the remaining blood at $8500 \mathrm{~g}$ for 15 minutes.

ii. Liver Extract. The liver was halved and both portions accurately weighed. One half was homogenized in $4.0 \mathrm{~mL} 4^{\circ} \mathrm{C} \quad 0.25 \mathrm{M}$ sucrose/g tissue, then centrifuged at $100,000 \mathrm{~g}$ and $4^{\circ} \mathrm{C}$ for 30 minutes [17]. The supernatant was collected and frozen.

iii. Glycogen Extract. The second liver section was digested in $3.0 \mathrm{~mL} 30 \% \mathrm{w} / \mathrm{v}$ $\mathrm{KOH}$ in an $85-90^{\circ} \mathrm{C}$ bath. The digest was diluted to $15.0 \mathrm{~mL}$ with $\mathrm{H}_{2} \mathrm{O}$. A $3.0 \mathrm{~mL}$ aliquot was mixed with $4.5 \mathrm{~mL} 95 \%$ ethanol in a glass centrifuge tube, then replaced in the bath until flocculation ceased. The tube was cooled to RT then centrifuged at $45,000 \mathrm{~g}$ for 10 minutes. The supernatant was discarded, and the precipitate air dried and resuspended in $4.00 \mathrm{~mL} \mathrm{H}_{2} \mathrm{O}$ [18].

iv. Plasma $\beta$-Hydroxybutyrate. A reference was prepared with $0.80 \mathrm{~mL} \mathrm{H}_{2} \mathrm{O}, 0.10 \mathrm{~mL}$ 10X Buffer A (1.0M Tris, 20mM EDTA \& $200 \mathrm{mM}$ oxalic acid; $\mathrm{pH} 9.0$ ), $40.0 \mu \mathrm{L} 75 \mathrm{mM}$ $\mathrm{NAD}^{+}$in $1 \mathrm{X}$ Buffer $\mathrm{A}$, and $60.0 \mu \mathrm{L} 1 \mathrm{mM}$ BHBT in $150 \mathrm{mM} \mathrm{NaCl}$. A test sample was prepared with $0.83 \mathrm{~mL} \mathrm{H}_{2} \mathrm{O}, 0.10 \mathrm{~mL} 10 \mathrm{X}$
Buffer A, 40.0 $\mu \mathrm{L} 75 \mathrm{mM} \mathrm{NAD}^{+}$in 1 X Buffer A, and $30.0 \mu \mathrm{L}$ plasma. After RT incubation, $7.0 \mu \mathrm{L} 30 \mathrm{mUnits} / \mu \mathrm{L}$ BHBT dehydrogenase ( $\beta$ HBTDH; EC 1.1.1.30) was added to both samples. $A_{340 \mathrm{~nm}}$ was determined prior to $\beta H B T D H$ addition, and every minute thereafter until $\Delta A_{340 \mathrm{~nm}} / \mathrm{min}$ of the reference reached zero.

v. Liver Glucose-6-Phosphate Dehydrogenase. A reference was prepared with $0.67 \mathrm{~mL} \mathrm{H}_{2} \mathrm{O}, 0.95 \mathrm{~mL}$ Buffer $\mathrm{B}(0.093 \mathrm{M}$ Tris$\mathrm{HCl}, 7.0 \mathrm{mM} \mathrm{MgCl}_{2} ; \mathrm{pH} 7.6$ ), and $0.35 \mathrm{~mL}$ $1 \mathrm{mM} \mathrm{NADP}{ }^{+}$in Buffer $B$. A test sample was prepared with $0.25 \mathrm{~mL} \mathrm{H}_{2} \mathrm{O}, 0.95 \mathrm{~mL}$ Buffer $B$, and $0.35 \mathrm{~mL} 1 \mathrm{mM} \mathrm{NADP}^{+}, 0.35 \mathrm{~mL}$ $5.00 \mathrm{mM}$ G6P, and $70 \mu \mathrm{L} 1 \mathrm{Unit} / \mathrm{mL} 6-$ phosphogluconate dehydrogenase (EC 1.1.1.44). After RT incubation, $30.0 \mu \mathrm{L}$ liver extract was added to both samples and $\Delta \mathrm{A}_{340 \mathrm{~nm}} / \mathrm{min}$ determined over the next 10 minutes.

vi. Liver Serine Dehydratase. A reference was prepared with $1.00 \mathrm{~mL} \mathrm{H}_{2} \mathrm{O}, 0.53 \mathrm{~mL}$ Buffer C $(.064 \mathrm{M}$ Tris- $\mathrm{HCl}, .062 \mathrm{M} \mathrm{KCl}$, $0.16 \mathrm{mM}$ pyridoxal phosphate, $4 \mathrm{mM}$

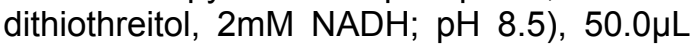
30 Units $/ \mathrm{mL}$ lactate dehydrogenase (EC 1.1.1.27) in Buffer $C$, and $20.0 \mu \mathrm{L}$ liver extract. A test sample was prepared identically, though using $0.80 \mathrm{~mL} \mathrm{H}_{2} \mathrm{O}$. After RT incubation, $0.20 \mathrm{~mL}$ RT $1.0 \mathrm{M}$ L-serine was added to the test sample and $\Delta \mathrm{A}_{340 \mathrm{~nm}} / \mathrm{min}$ of both samples determined over the next 10 minutes [19].

vii. Liver Glycogen and Protein Content. Aliquots of $0.30 \mathrm{~mL} 1: 1,1: 4,1: 8$, and $1: 16$ diluted glycogen resuspensions were assayed with $3.0 \mathrm{~mL}$ anthrone reagent $(0.55 \mathrm{~g}$ anthrone in $1.0 \mathrm{~L}$ concentrated sulfuric acid and $352 \mathrm{~g}$ ice) at $620 \mathrm{~nm}$ as described by Johann and Lentini using $30.00 \mu \mathrm{g} / \mathrm{mL}, 60.00 \mu \mathrm{g} / \mathrm{mL}$, and $100.0 \mu \mathrm{g} / \mathrm{mL}$ high-grade dextrose standard solutions. The liver glycogen content was calculated [18]. The liver extract protein content was determined via Bradford assay using bovine serum albumin standard [20].

\section{e. Statistical Analysis}

Significance between group weights was determined using Student's $t$-test. The significance of other data was indeterminable, due to the limited number of mice per data point. A third control mouse was available for sacrifice at 19 weeks, and 
was used to determine intra-group standard deviation for tissue weights and blood analyses.

\section{RESULTS}

\section{a. Observations}

Survival up to euthanasia was $100 \%$ for all mice. The LC mice had oily fur, and $30 \%$ developed bald patches on their heads or around their abdomens. As fur regrew in bald areas when the affected mice were transferred to their individual metabolic cage, this phenomenon was attributed to aggressive cage-partner grooming, possibly as a result of their high oil secretion. LC feces were generally hard, lightly hued, and non-aromatic, whereas $\mathrm{HC}$ feces were soft, dark, and pungent.

\section{b. Intake And Excretion}

Average caloric intake in the LC group was elevated during the first 3 weeks at $24.8 \mathrm{kcal} / \mathrm{d}$ before decreasing to $15.7 \mathrm{kcal} / \mathrm{d}$ for the remaining 16 weeks, while the $\mathrm{HC}$ group consumed close to an average of $19.6 \mathrm{kcal} / \mathrm{d}$ throughout the study. (Figure 1) Consistent with the composition of the diets, fat and $\mathrm{CHO}$ intake was different between groups. The $\mathrm{HC}$ mice consumed an average of $3.07 \mathrm{~g} / \mathrm{d}$ of $\mathrm{CHO}$ and $0.23 \mathrm{~g} / \mathrm{d}$ of fat versus $0.22 \mathrm{~g} / \mathrm{d}$ of $\mathrm{CHO}$ and $1.17 \mathrm{~g} / \mathrm{d}$ of fat in the LC mice. However, absolute daily protein intake was not appreciably different between groups. Though LC protein consumption was initially elevated at an average of $2.43 \mathrm{~g} / \mathrm{d}$ over the first 3 weeks, afterwards, as total food intake declined, it decreased to $1.54 \mathrm{~g} / \mathrm{d}$, where it fluctuated close to control values, which averaged $1.45 \mathrm{~g} / \mathrm{d}$ over the entire study. (Figure 2) Initial water intake was similar between LC and HC mice; both groups decreased from $30 \mathrm{~mL} / \mathrm{d}$ initially through week 5 to fluctuate between $5-15 \mathrm{~mL} / \mathrm{d}$ thereafter.

Urine output in the LC group was elevated above control values (ave. 3.2 vs. $1.5 \mathrm{~mL} / \mathrm{d}$, respectively) during the first 7 weeks. Afterward, LC urine output was not appreciably higher than $\mathrm{HC}$ output; during the final 6 weeks, average daily urine output was identical between groups at $2.04 \mathrm{~mL} /$ day. Defecation was higher in the
HC group than the LC group (1.8 vs. $0.4 \mathrm{~g} / \mathrm{d}$, respectively), due in part to the higher fiber content of the $\mathrm{HC}$ diet.

\section{c. Body Weight And Composition}

During the first 4 weeks the LC mice grew at an average rate of $0.45 \mathrm{~g} / \mathrm{d}$ versus $0.30 \mathrm{~g} / \mathrm{d}$ in the $\mathrm{HC}$ group. After 3 weeks, the LC mice were significantly heavier $(p<0.05$; $p<0.005$ at 4 wks; $n=16$ per group, both weeks), whereas $\mathrm{HC}$ mouse weights were consistent with ICR standard growth throughout the study. At week 5 growth rates in both groups decreased to $0.1 \mathrm{~g} / \mathrm{d}$; while the mean $\mathrm{HC}$ mouse weight leveled off at approximately $40 \mathrm{~g}$ at week 8 , the LC mice continued to gain weight through the end of the study. (Figure 3)

After week 3 , the abdominal adipose deposits in the LC mice were more extensive than in the $\mathrm{HC}$ mice. In the former group, abdominal adipose increased from $3.0 \%$ of BW at week 3 to $6.6 \%$ by week 19 , whereas the latter decreased from $3.0 \%$ to $2.6 \pm 1.2 \%$ during the same period. (Figure 4) Mean absolute liver weights were not appreciably different between the LC and $\mathrm{HC}$ groups. However, relative liver weights were lower in the LC mice after 5 weeks due to the increased weight gain in the group.

\section{d. Liver Composition}

Liver glycogen levels were not apparently different between groups, nor were LC values suppressed from initial levels (Figure 5). Liver protein content in the LC group was higher than control values (ave. 9.8 vs. $8.3 \%$ by mass, respectively) during the first 11 weeks. However, after this point, LC and $\mathrm{HC}$ values fluctuated around $10 \%$, such that by 19 weeks there was no considerable difference between groups (Figure 6).

e. Hepatic Enzyme Activity

Liver G6PDH activity in the LC mice gradually increased from 0.131 to $0.244 \mathrm{U} / \mathrm{g}$ over 19 weeks; inhibition from initial levels was not observed at any point. However, mean LC G6PDH activity from weeks 9-19 was lower than $\mathrm{HC}$ activity (average 0.193 vs. $0.304 \mathrm{U} / \mathrm{g}$, respectively). Final activities were virtually the same between the LC and 


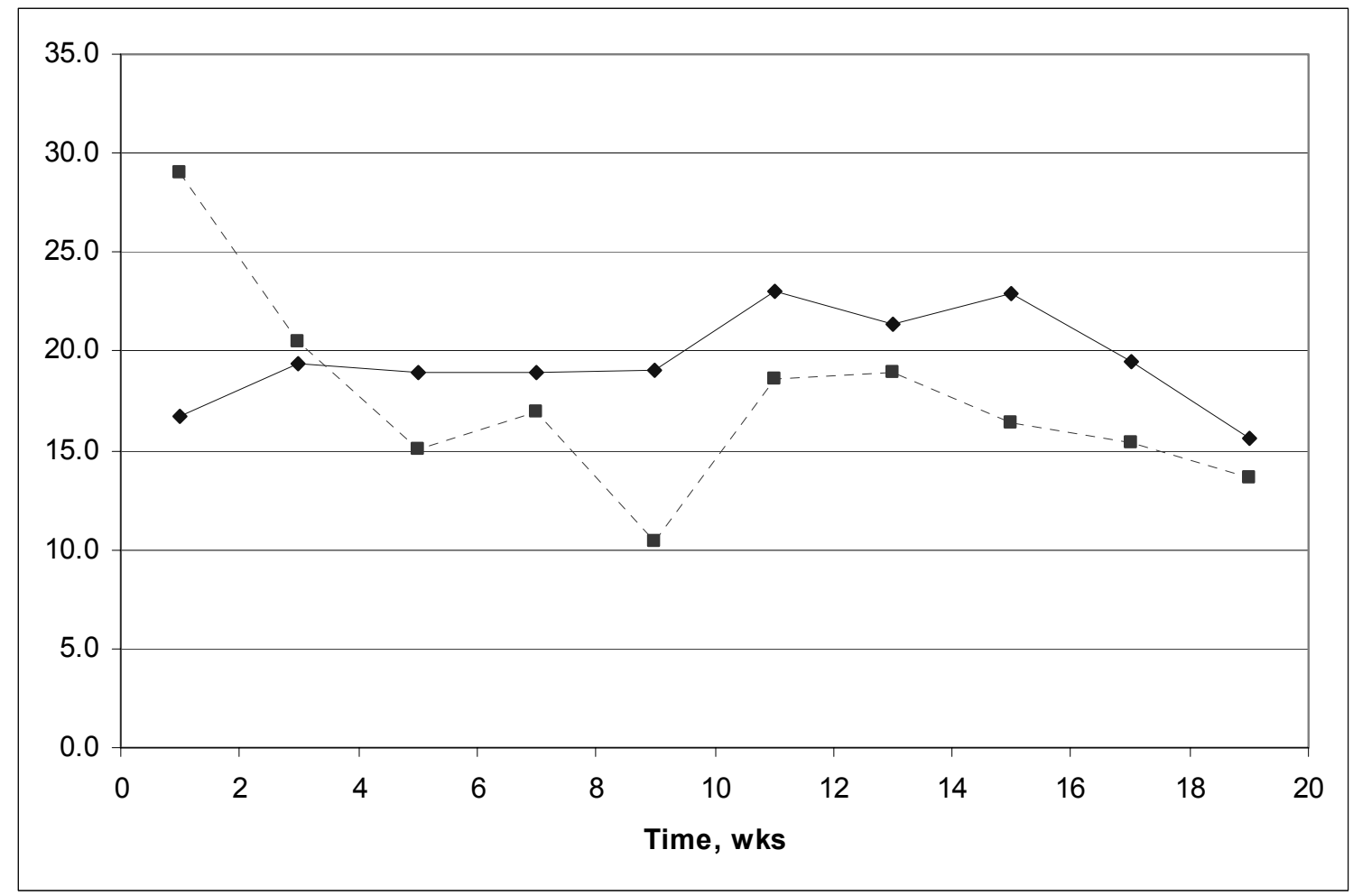

Figure 1. Daily caloric intake, $k c a l / d$.

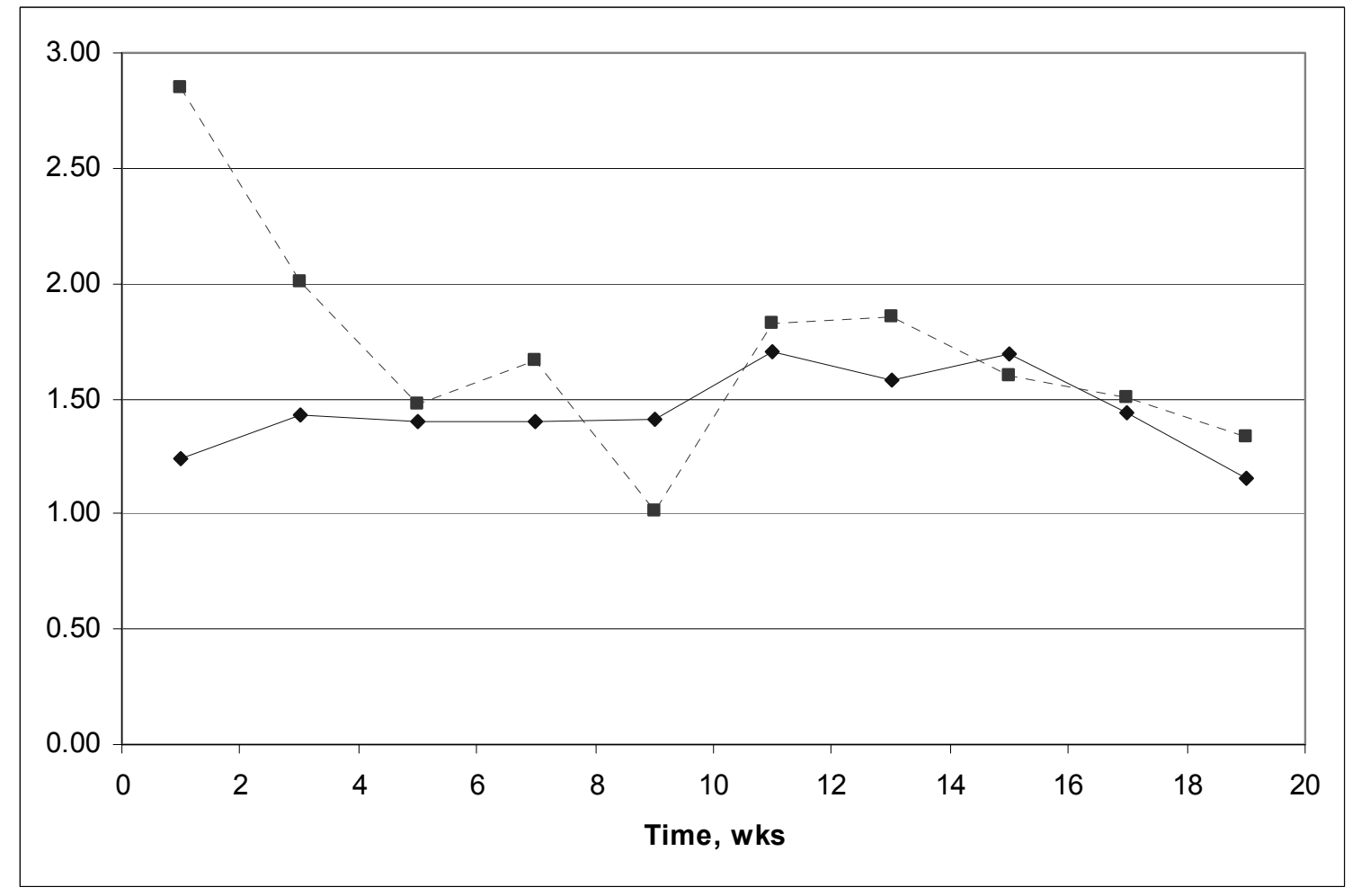

Figure 2. Absolute daily protein consumption, $g / d$. 


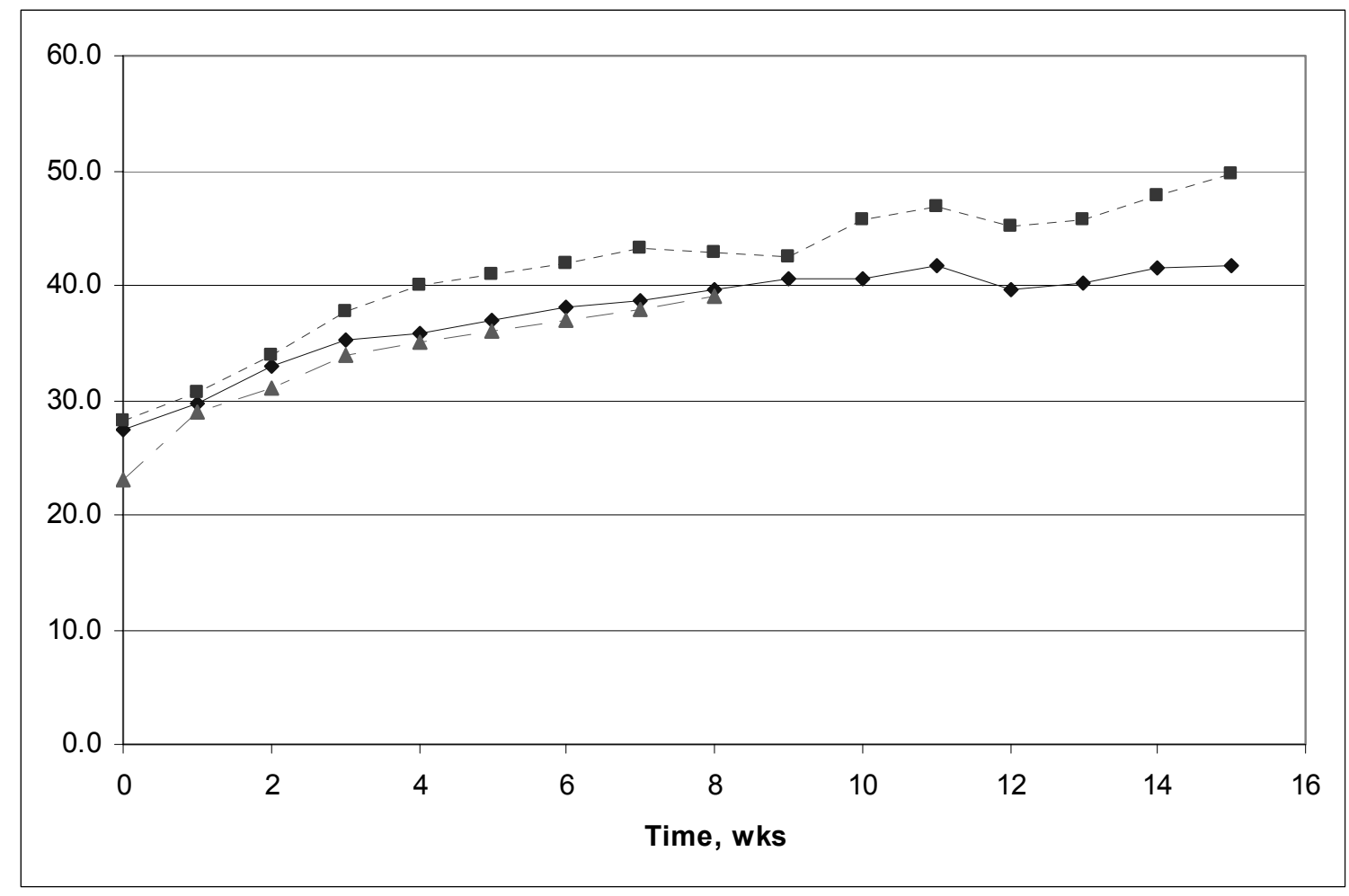

Figure 3. Mouse weight, grams; with ICR mouse growth curve. For LC and HC data, each point is the mean of all remaining paired mice per group. At even weeks $t, n=20-t$.

HC groups (0.244 vs. $0.247 \mathrm{U} / \mathrm{g}$, respectively) (see Figure 7).

Liver SDH specific activity in the LC group was elevated above control levels over the first 3 weeks. Activity in the LC and $\mathrm{HC}$ groups peaked at 1.332 and $1.129 \mathrm{U} / \mathrm{g}$, respectively, at week 5 before both decreasing to fluctuate near starting levels by week 19 (see Figure 8 ).

\section{f. Blood And Plasma Metabolites}

Total whole blood cholesterol (TC) concentration in the LC group increased after week 11 from 101 to $203 \mathrm{mg} / \mathrm{dL}$ by week 19; prior, LC TC levels had fluctuated near $120 \mathrm{mg} / \mathrm{dL}$. HC TC decreased slightly from initial levels and remained near $100 \mathrm{mg} / \mathrm{dL}$ for most of the study (Figure 9). From week 3 on, plasma HDL concentrations in the LC group were elevated relative to both initial and control levels. HDL increased from 55 to $100 \mathrm{vs.}$ $68 \pm 2 \mathrm{mg} / \mathrm{dL}$ in the LC and HC groups, respectively (see Figure 10).
Plasma $\beta$ HBT concentration in the LC group was elevated over $\mathrm{HC}$ values during the first week (344 vs. $78 \mu \mathrm{M}$, respectively). However, LC $\beta$ HBT levels returned to near control values by week 5 . BHBT concentrations increased in both groups during weeks 7 through 9, corresponding with a week-long accidental fast. Afterwards, LC levels remained elevated relative to control values; allowing for the peaks at weeks 7 and 9, LC BHBT concentrations were higher than in the $\mathrm{HC}$ group (124 vs. $64 \mu \mathrm{M}$, respectively). (Figure $\mathrm{XI})$ Blood glucose concentration in the LC mice was suppressed relative to both initial and control values through week 7 . Afterward, LC glucose levels returned to near initial and $\mathrm{HC}$ levels (Figure 12).

No clear trends in blood VLDL and triacylglyceride (TRG) levels were observed, as these values fluctuated significantly in both groups. Throughout the study, both LC and HC VLDL and TRG levels remained within the standard deviations of the final $\mathrm{HC}$ point for these values $(26 \pm 14$ and $130 \pm 68$ $\mathrm{mg} / \mathrm{dL}$, respectively). LDL values were 


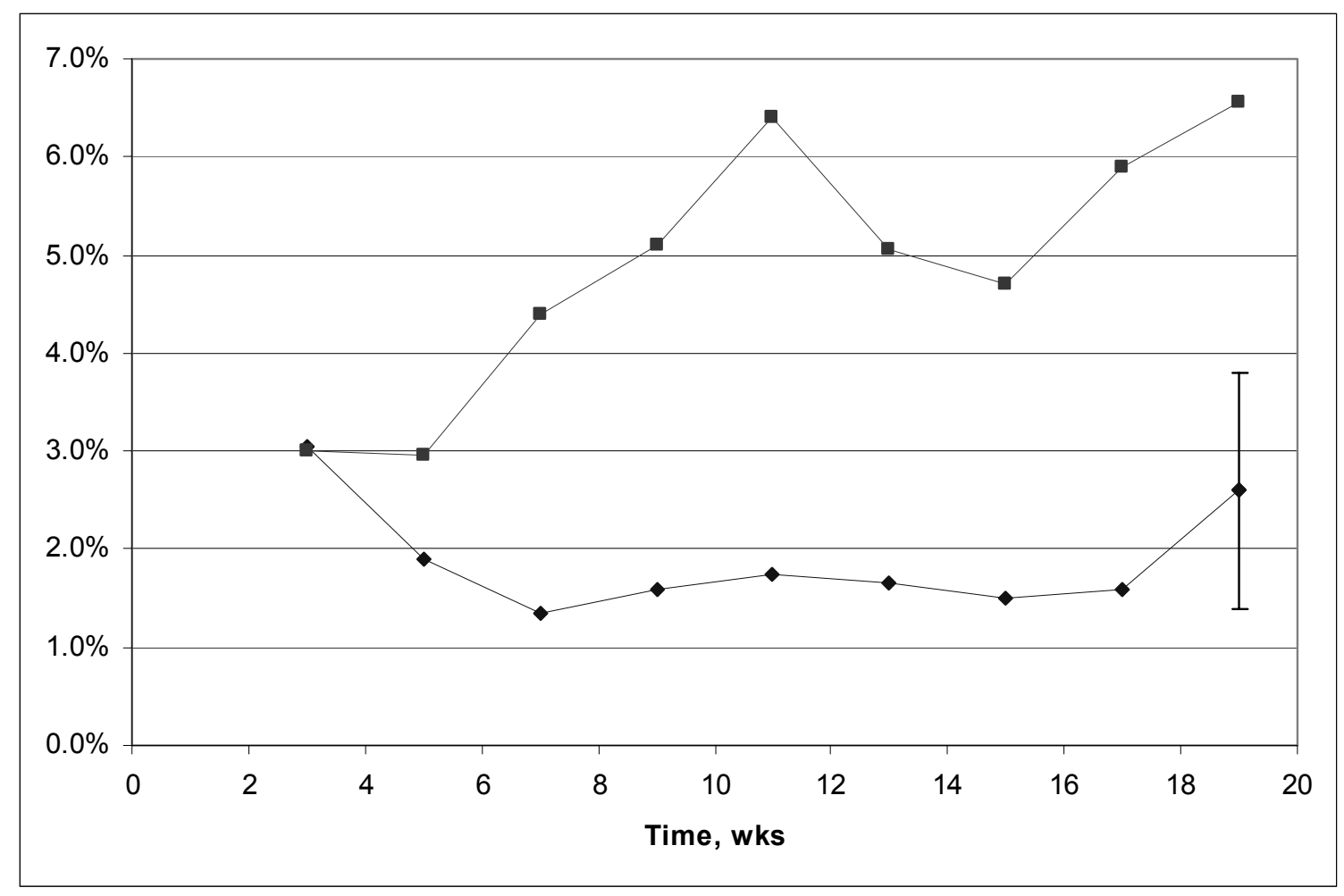

Figure 4. Subcutaneous abdominal adipose tissue, \%body mass.

returned for only 13 of 43 samples tested; this data is not included.

\section{FIGURES}

For all figures, LC data is plotted with dotted lines with square points, $\mathrm{HC}$ with solid lines with diamond points, and reference data with broken lines with triangular points when available. For LC and $\mathrm{HC}$ data, each point is the mean of two values unless otherwise noted.

\section{DISCUSSION}

A notable limitation of this study was the use of only two mice per data point, a restriction necessitated by technical limitations and which prevented statistical analysis within points and between groups. However, most paired data correlated well and was validated when it appeared otherwise. The animals were not fasted prior to sacrifice, which may have skewed some results, particularly blood metabolite profiles, and may account for the extreme fluctuation exhibited in the TRG and VLDL data. However, the low standard deviation of the final TC and HDL data suggests this effect may be limited. Further research incorporating more animals per point and a pre-sacrifice fast would be necessary to provide a more accurate determination of the effects of the LC diet. Finally, handling of the mice immediately prior to sedation likely produced a sympathetic nervous system response that would have also influenced results, notably liver glycogen and blood glucose levels [21]. However, this procedure was performed as consistently as possible to minimize these effects.

The LC mice consumed, ad libitum, an average of $20 \%$ fewer kilocalories per day from the fifth week on (see Figure 1). Anorexia is consistent with literature findings of diets high in protein and/or fat in both murine and human subjects, and has been attributed to both increased satiety and greater efficiency of adipose deposition from dietary fat than $\mathrm{CHO}[6,8,12,13,22-26]$. However, contrary to published reports that $\mathrm{CHO}$ restriction itself promotes weight loss $[6,8,13]$, lower body weights were not observed in the LC group, despite induced 


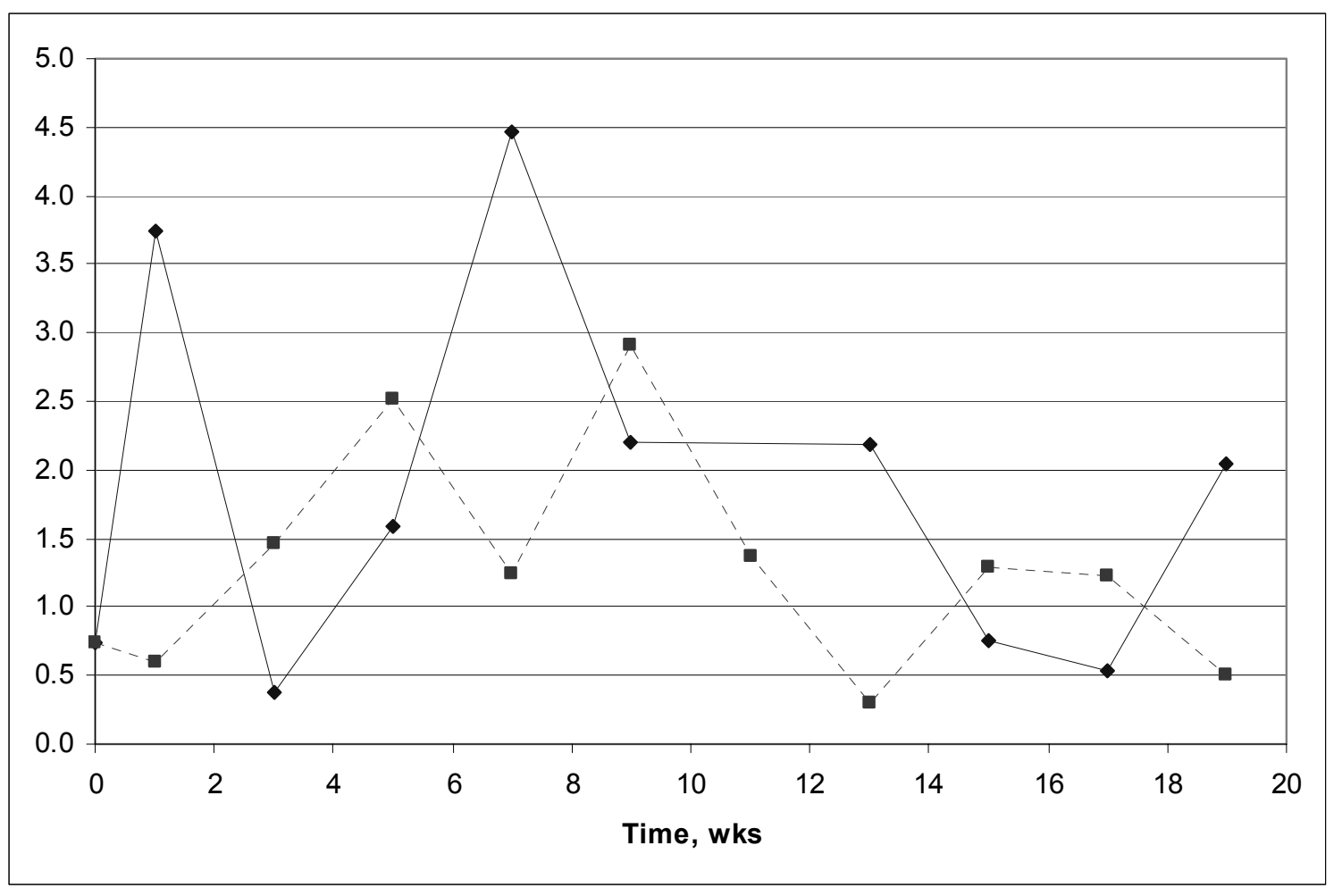

Figure 5. Liver glycogen content, \%liver mass.

caloric restriction. Rather, the mice on the LC diet gained significantly more weight and fat mass than those on the $\mathrm{HC}$ diet (see Figures 3 and 4). Further, whereas the LC group continued to gain weight above normal levels for ICR mice, the HC group maintained normal weight while reducing fat mass over the study. However, these growth responses may be specific to the ICR mouse strain, rather than solely the result of the LC and $\mathrm{HC}$ diet compositions, as dietary fat content differentially affects growth and development between mouse strains [27].

Despite the higher protein content of the LC diet, absolute protein consumption was virtually the same (approx. $1.5 \mathrm{~g} / \mathrm{d}$ ) between groups after the first five weeks of the study (Figure 2). As such, the LC and $\mathrm{HC}$ groups were defined by low- $\mathrm{CHO} /$ highfat, and low-fat/high-CHO intake, respectively. Although mean LC SDH activity was higher than $\mathrm{HC}$ levels (Table II), which probably represents increased gluconeogenic activity, activity in both groups displayed similar overall trends. (Figure VIII) Considering male ICR protein requirements for normal growth is $1.0 \mathrm{~g} / \mathrm{d}$ [27] the mice in both groups consumed an excess of protein throughout the study, which may account for these patterns. In addition to its role in gluconeogenesis during $\mathrm{CHO}$ restriction $[22,28]$, hepatic $\mathrm{SDH}$ is involved in maintenance of nitrogen homeostasis via degradation of excess amino acids, regardless of glucose status [29]. Finally, as the percentage of protein available in each diet was fixed, the virtually identical protein intakes may be a coincidental result of the groups' differential food intake, or absolute protein intake may have played a role in regulating total food intake.

Average HC G6PDH activity was elevated above LC and initial levels after week 7 , though $\mathrm{HC}$ enzyme activity fluctuated greatly during this period (see Figure 7). Whether this trend represents a true elevation in HC G6PDH activity rather than diurnal fluctuations was indeterminable, as the animals were not fasted prior to sacrifice [30]. Thus, the observed suppression in LC G6PDH relative to HC activity may signify either long-term enzyme 
inhibition or short-term suppressed inducibility. The former is consistent with the high lipid content of the former group's diet (see Table 1); diets high in fat have been shown to inhibit G6PDH, an important lipogenic enzyme [14,31]. Further, LC G6PDH activity was not suppressed from initial values, but rather increased over the course of the study, which would have allowed for a degree of continued ribose and NADPH synthesis through the pentose phosphate pathway. As the enzyme's activity is additionally responsive to glucose status and dietary CHO levels $[14,30,31]$ this suggests that hepatocyte glucose-6phosphate concentrations did not significantly decrease in the LC group, and ancillary, non-glycolytic glucose metabolism was not adversely affected.

Absolute liver weight did not appreciably change within or between groups during the study (Table 2). Consistent with the finding that liver weight is proportional to liver glycogen content [25, 32], no differences in average hepatic glycogen levels were observed either (see Figure 5). Contrary to published reports that severe $\mathrm{CHO}$ restriction induces hepatic glycogen depletion [7,12], LC liver glycogen levels were not suppressed below $\mathrm{HC}$ or initial levels, again suggesting long term conservation of normal intracellular hepatic G6P concentrations. As glycogen synthesis often relies on endogenous glucose production [14], the high protein content of the LC diet apparently facilitated hepatic G6P and glycogen maintenance. Indeed, liver glycogenesis is promoted by cortisol in response to gluconeogenesis from amino acid substrates following protein degradation [21]. However, maximal liver glycogen levels differed between LC and $\mathrm{HC}$ groups ( 2.91 vs. $4.47 \%$ by mass, respectively), and may represent a degree of suppression of glycogen synthesis. Finally, the observed fluctuations in hepatic glycogen content may be diurnal, or the result of epinephrine induced glycogen breakdown resulting from a sympathetic nervous response to trapping and handling the mice immediately prior to sedation [14,21].

Consistent with maintenance of hepatic glycogen, which significantly contributes to sustaining and modulating blood glucose [14, 33], final LC plasma glucose was not greatly different from $\mathrm{HC}$ or

\begin{tabular}{|c|c|c|}
\hline Nutrients & LC & $\mathrm{HC}$ \\
\hline & \multicolumn{2}{|c|}{ Grams per $100 \mathrm{~g}$ Diet } \\
\hline Casein & 49.262 & na \\
\hline Cellulose & 1.845 & 20.7 \\
\hline Corn Oil & 6.150 & na \\
\hline Dextrin & 3.075 & na \\
\hline Fructose & 0.000 & 0.36 \\
\hline Glucose & 0.000 & 0.31 \\
\hline Insulin & 1.845 & na \\
\hline Lard & 27.823 & na \\
\hline $\begin{array}{l}\text { Mineral } \\
\text { mixture }\end{array}$ & 6.150 & 6 \\
\hline Starch & 0.000 & 38.6 \\
\hline Sucrose & 0.959 & 3.31 \\
\hline $\begin{array}{l}\text { Vitamin } \\
\text { mixture }\end{array}$ & 2.460 & na \\
\hline Carbohydrate & 6.37 & 63.46 \\
\hline Fat & 33.97 & 4.80 \\
\hline Protein & 49.45 & 29.94 \\
\hline Other & 10.21 & 1.80 \\
\hline & \multicolumn{2}{|c|}{ kcal per $100 \mathrm{kcal}$ diet } \\
\hline Carbohydrate & 5.00 & 62.68 \\
\hline Fat & 60.00 & 10.66 \\
\hline Protein & 35.00 & 26.66 \\
\hline & \multicolumn{2}{|c|}{ kcal per $100 \mathrm{~g}$ diet } \\
\hline Carbohydrate & 25.48 & 253.85 \\
\hline Fat & 305.76 & 43.17 \\
\hline Protein & 178.35 & 107.97 \\
\hline Total & 509.6 & 405.00 \\
\hline
\end{tabular}

Table 1. Summary of LC and HC diets. LC caloric profile adapted from Kappagoda et al. [12]. HC nutritional data adapted from PTD [39].

initial values. Indeed, adherence to a $\mathrm{CHO}$ restricted diet for longer than three months did not significantly affect blood glucose levels in non-diabetic human subjects $[5,11,34]$. However, four-week consumption of low-CHO diets has been shown to decrease human blood glucose levels [35], which may account for the suppressed LC glucose levels observed from weeks one to seven. 


\begin{tabular}{|c|c|c|c|c|}
\hline Variable & Initial & Final & Average & Range $^{\text {week }}$ \\
\hline \multicolumn{5}{|l|}{ Weight, g } \\
\hline LC & 28.1 & 49.8 & 41.5 & $25.0^{1}-50.9^{13}$ \\
\hline $\mathrm{HC}$ & 27.5 & 41.7 & 37.5 & $25.7^{1}-44.9^{13}$ \\
\hline \multicolumn{5}{|l|}{ Food intake, $\mathrm{kcal} / \mathrm{d}$} \\
\hline LC & 29.0 & 13.6 & 17.5 & $13.6^{19}-29.0^{1}$ \\
\hline $\mathrm{HC}$ & 16.7 & 15.6 & 19.6 & $15.6^{19}-23.1^{11}$ \\
\hline \multicolumn{5}{|l|}{ Water intake, $\mathrm{mL} / \mathrm{d}$} \\
\hline LC & 29.8 & 5.8 & 11.8 & $5.6^{17}-29.8^{1}$ \\
\hline $\mathrm{HC}$ & 31.8 & 10.0 & 14.4 & $8.8^{15}-31.8^{1}$ \\
\hline \multicolumn{5}{|l|}{ Urine output, $\mathrm{mL} / \mathrm{d}$} \\
\hline LC & 3.5 & 0.9 & 2.4 & $0.9^{19}-4.2^{3}$ \\
\hline $\mathrm{HC}$ & 2.2 & 0.4 & 1.9 & $0.4^{19}-3.0^{9}$ \\
\hline \multicolumn{5}{|l|}{ Feces output, g/d } \\
\hline LC & 0.62 & 0.36 & 0.44 & $0.33^{5}-0.62^{1}$ \\
\hline $\mathrm{HC}$ & 2.64 & 1.03 & 1.78 & $1.03^{19}-2.64^{1}$ \\
\hline \multicolumn{5}{|l|}{ Protein intake, $\mathrm{g} / \mathrm{d}$} \\
\hline LC & 2.84 & 1.33 & 1.71 & $1.02^{9}-2.84^{1}$ \\
\hline $\mathrm{HC}$ & 1.24 & 1.15 & .45 & $1.40^{5}-1.71^{11}$ \\
\hline \multicolumn{5}{|l|}{ Abdominal fat, $\%$ body mass } \\
\hline LC & 3.0 & 6.6 & 5.1 & $3.0^{1}-8.6^{11}$ \\
\hline $\mathrm{HC}$ & 3.1 & $2.6 \pm 1.2$ & .8 & $1.4^{7}-3.1^{1}$ \\
\hline \multicolumn{5}{|l|}{ Absolute liver weight, $\mathrm{g}$} \\
\hline LC & 1.55 & 1.64 & 1.75 & $1.55^{0}-2.05^{11}$ \\
\hline $\mathrm{HC}$ & 1.55 & $1.96 \pm 0.12$ & 1.83 & $1.47^{3}-2.03^{1}$ \\
\hline \multicolumn{5}{|l|}{ Liver protein content, $\%$ mass } \\
\hline LC & 8.6 & 10.4 & 9.7 & $8.5^{3}-11.6^{11}$ \\
\hline $\mathrm{HC}$ & 8.6 & 9.2 & 9.0 & $8.0^{1}-11.1^{13}$ \\
\hline
\end{tabular}

Table 2a. Summary of results. Initial values are at one week for all intakes, outputs, and BHBT, and at zero weeks for all other data. Final values for weight are at 15 weeks, and at 19 weeks for all other data. See Table $2 b$ (at right) for the remainder of the survey.

Concomitant with the initial decrease in plasma glucose, LC BHBT levels were elevated at week one before rapidly returning to near control values. This initial trend is consistent with human $\beta \mathrm{HBT}$ responses to $\mathrm{CHO}$ reduced diets [36], though the $\beta H B T$ results in this study were particularly susceptible to the accidental fast at week 8 , preventing accurate long term analysis. However, studies following human $\beta H B T$ responses to a low- $\mathrm{CHO}$ diet have found that while $\beta \mathrm{HBT}$ remained significantly elevated at three months, it had returned to near normal by six months [34]. Further, the rise in plasma $\beta H B T$ in both groups over weeks 7 and 9 , suggests that sustained ketone body production requires a prolonged, severe caloric restriction in addition to, or in the case of the $\mathrm{HC}$ group rather than, dietary $\mathrm{CHO}$ reduction.
However, it is important to note that $\beta \mathrm{HBT}$ is only one of three ketone bodies produced and metabolized during $\mathrm{CHO}$ restriction or fasting, and that the other two, acetoacetate and acetone, were not assessed in this study $[14,21]$.

Blood TC and HDL both increased in the LC group over $\mathrm{HC}$ and initial levels, whereas HC TC decreased from initial values despite a rise in $\mathrm{HDL}$ concentration (see Figures 9, 10). The increase in LC TC is due in part to elevated HDL, though it is also likely a result of increased body fat composition $[5,7,14]$. The increased HDL in the LC group is consistent with other studies of low-CHO diets that report favorable changes in serum HDL; this phenomenon has been attributed partly to decreased plasma VLDL cholesterol and TRG levels $[5,6]$, though these effects were not 


\begin{tabular}{|c|c|c|c|c|}
\hline Variable & Initial & Final & Average & Range $^{\text {week }}$ \\
\hline \multicolumn{5}{|l|}{ Liver glycogen content, \% mass } \\
\hline LC & 0.74 & 0.51 & 1.29 & $0.30^{13}-2.91^{9}$ \\
\hline $\mathrm{HC}$ & 0.74 & 2.05 & 1.86 & $0.37^{3}-3.74^{1}$ \\
\hline \multicolumn{5}{|l|}{ Liver SDH activity, U/g } \\
\hline LC & 0.41 & 0.28 & 0.65 & $0.28^{19}-1.33^{5}$ \\
\hline $\mathrm{HC}$ & 0.41 & 0.54 & 0.44 & $0.08^{3}-1.13^{5}$ \\
\hline \multicolumn{5}{|l|}{ Liver G6PDH activity, U/g } \\
\hline LC & 0.13 & 0.24 & 0.18 & $0.13^{0}-0.24^{19}$ \\
\hline $\mathrm{HC}$ & 0.13 & 0.25 & 0.24 & $0.13^{0}-0.54^{17}$ \\
\hline \multicolumn{5}{|l|}{ Blood HDL, mg/dL } \\
\hline LC & 55.5 & 100.0 & 82.3 & $52.0^{1}-100.0^{19}$ \\
\hline $\mathrm{HC}$ & 55.5 & $68.0 \pm 2.0$ & 69.0 & $55.5^{0}-89.5^{15}$ \\
\hline \multicolumn{5}{|l|}{ Blood TC, mg/dL } \\
\hline LC & 115.5 & 203.0 & 133.1 & $101.0^{11}-203.0^{19}$ \\
\hline $\mathrm{HC}$ & 115.5 & $109.0 \pm 2.0$ & 109.4 & $100.0^{7}-131.5^{3}$ \\
\hline \multicolumn{5}{|l|}{ Plasma $\beta \mathrm{HBT}, \mu \mathrm{M}$} \\
\hline LC & 344.5 & 112.5 & 131.2 & $77.7^{5}-344.5^{1}$ \\
\hline $\mathrm{HC}$ & 77.7 & 42.9 & 77.5 & $42.9^{19}-144.5^{7}$ \\
\hline \multicolumn{5}{|l|}{ Blood glucose, mg/dL } \\
\hline LC & 247.5 & 255.5 & 198.3 & $131.5^{5}-258.8^{15}$ \\
\hline $\mathrm{HC}$ & 247.5 & $280.0 \pm 47.0$ & 219.0 & $164.0^{11}-340.5^{15}$ \\
\hline \multicolumn{5}{|l|}{ Blood VLDL, mg/dL } \\
\hline LC & 17 & 19 & 22 & $14^{15}-32^{9}$ \\
\hline $\mathrm{HC}$ & 17 & $26 \pm 14$ & 20 & $13^{9}-29^{13}$ \\
\hline \multicolumn{5}{|l|}{ Blood TRG, mg/dL } \\
\hline LC & 83 & 92 & 102 & $58^{13}-161^{5}$ \\
\hline $\mathrm{HC}$ & 83 & $130 \pm 68$ & 89 & $23^{3}-143^{13}$ \\
\hline
\end{tabular}

Table 2b. Summary of results (continued). Initial values are at one week for all intakes, outputs, and $\beta \mathrm{HBT}$, and at zero weeks for all other data. Final values for weight are at 15 weeks, and at 19 weeks for all other data. See Table $2 a$ (at left) for the remainder of the survey.

confirmed in this study. However, no appreciable changes in VLDL or TRG were established between the LC and HC groups (Table 2). Rather, increased HDL from LCHFP diets may result from improved insulin sensitivity from decreased $\mathrm{CHO}$ intake $[5,6]$.

Maintenance of G6PDH activity, liver glycogen, and plasma glucose levels, and the initial, short term changes in BHBT observed in the LC mice suggest that metabolic shifts induced by the LC diet were relatively short term phenomena, and that the mice were able to adapt to the diet to provide for near-normal glucose metabolism. Between the limited $\mathrm{CHO}$ in the diet, and gluconeogenesis from protein and TRG degradation, the LC mice were apparently able to meet metabolic $\mathrm{CHO}$ demands. Accordingly, prolonged ketosis and its metabolic effects were not observed in the
LC group. Insofar as the reported benefits and effects of low-CHO diets rely on significant metabolic shifts from a glucoserich state to one of depletion, the regime and conditions applied here do not support longterm efficacy of such diets.

Contrary to the findings of studies of LC-HFP diets in humans, ad libitum consumption of the LC diet lead to weight and fat gain, despite induced anorexia. Further, severe and sustained suppression of glucose and glycogen levels and metabolism, and significant reliance on fatty acid oxidation was not observed. At least in the model and conditions utilized, this suggests that the LC-HFP macronutrient profile is insufficient to produce weight loss alone. Indeed, in a calorically controlled study in men, adherence to a LC-HFP 


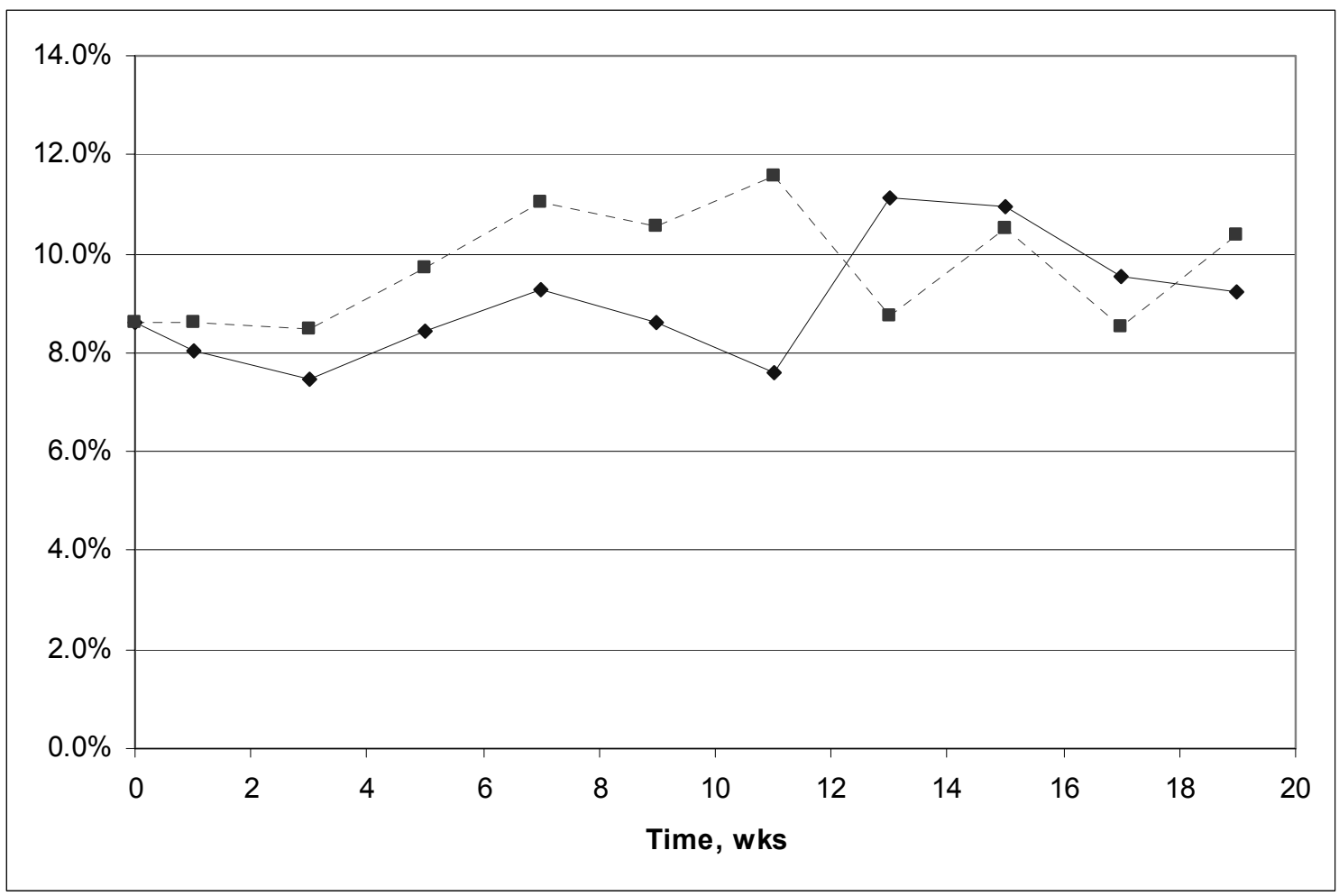

Figure 6. Liver protein content, \%liver mass.

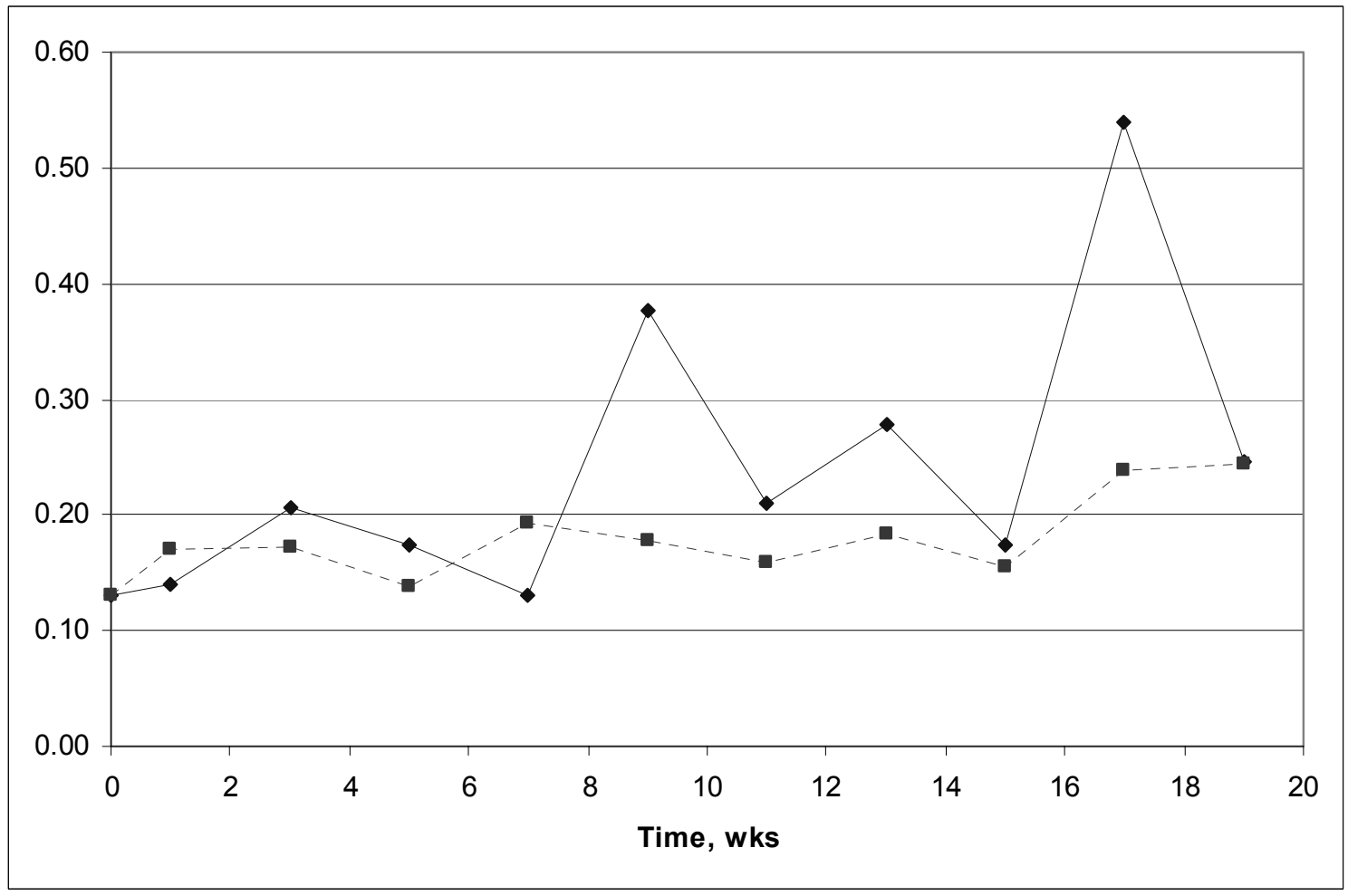

Figure 7. Liver G6PDH specific activity, U/g liver. 


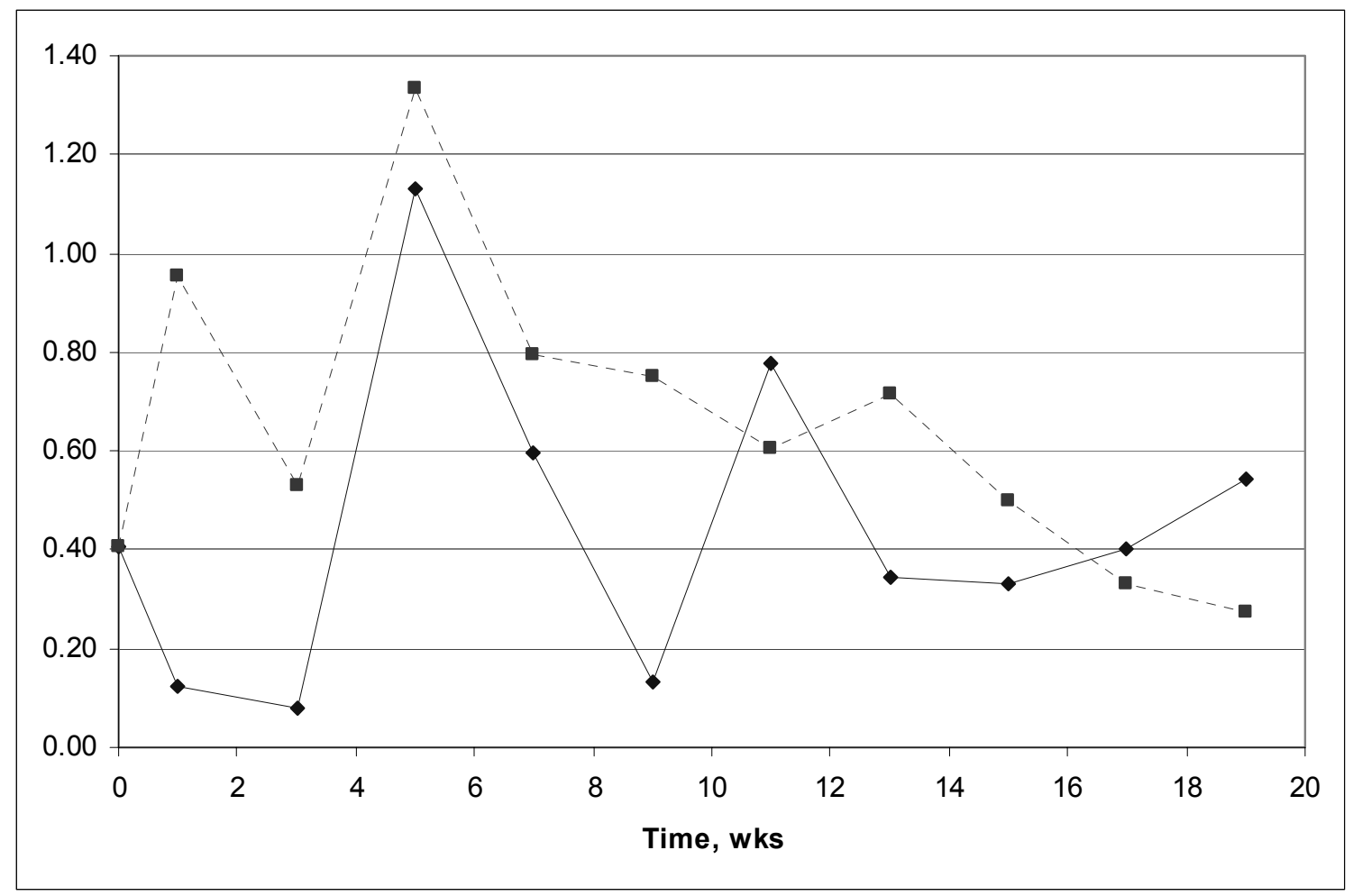

Figure 8. Liver SDH specific activity, U/g liver.

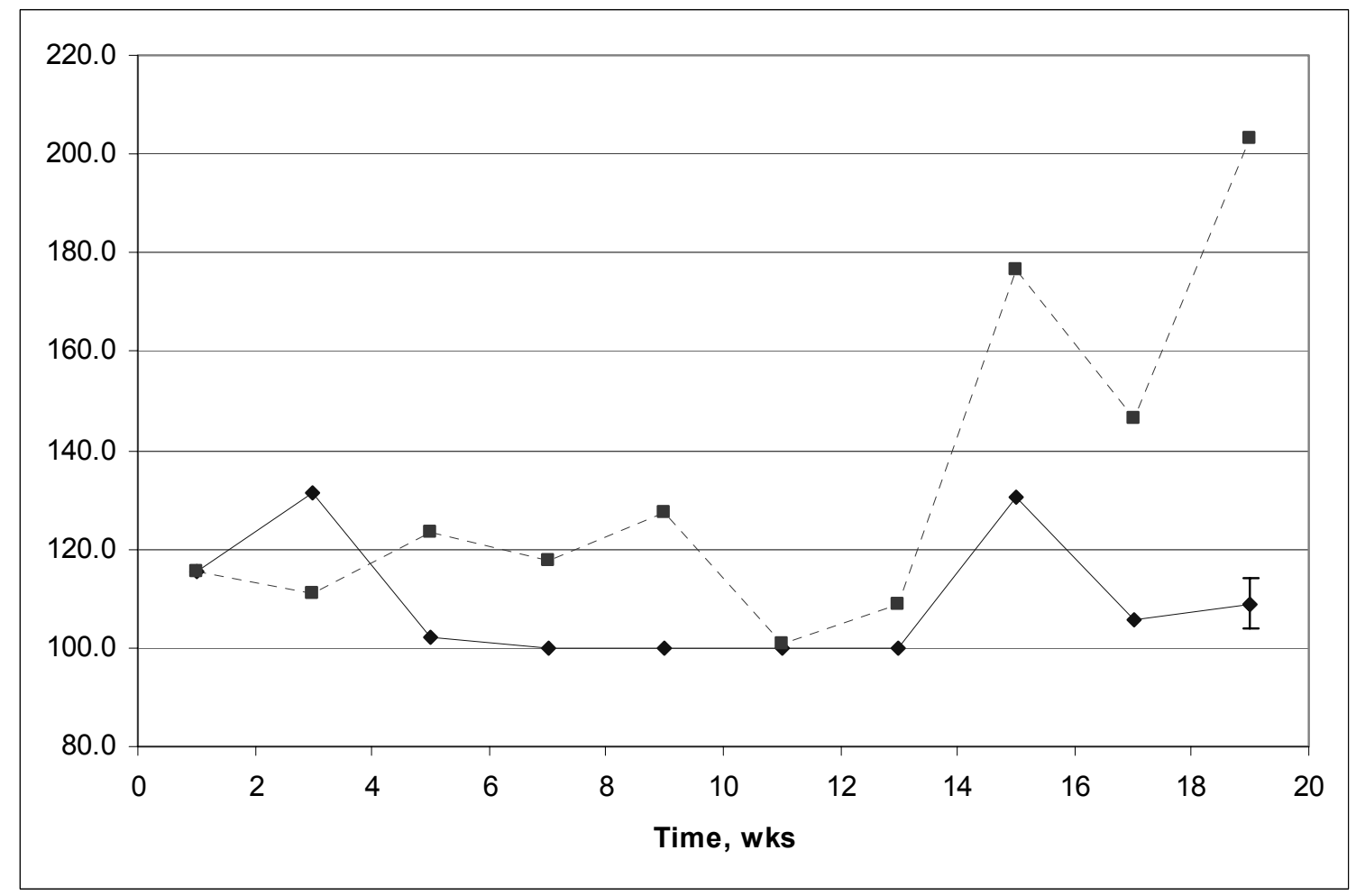

Figure 9. Total blood cholesterol concentration, $m g / d L$. 


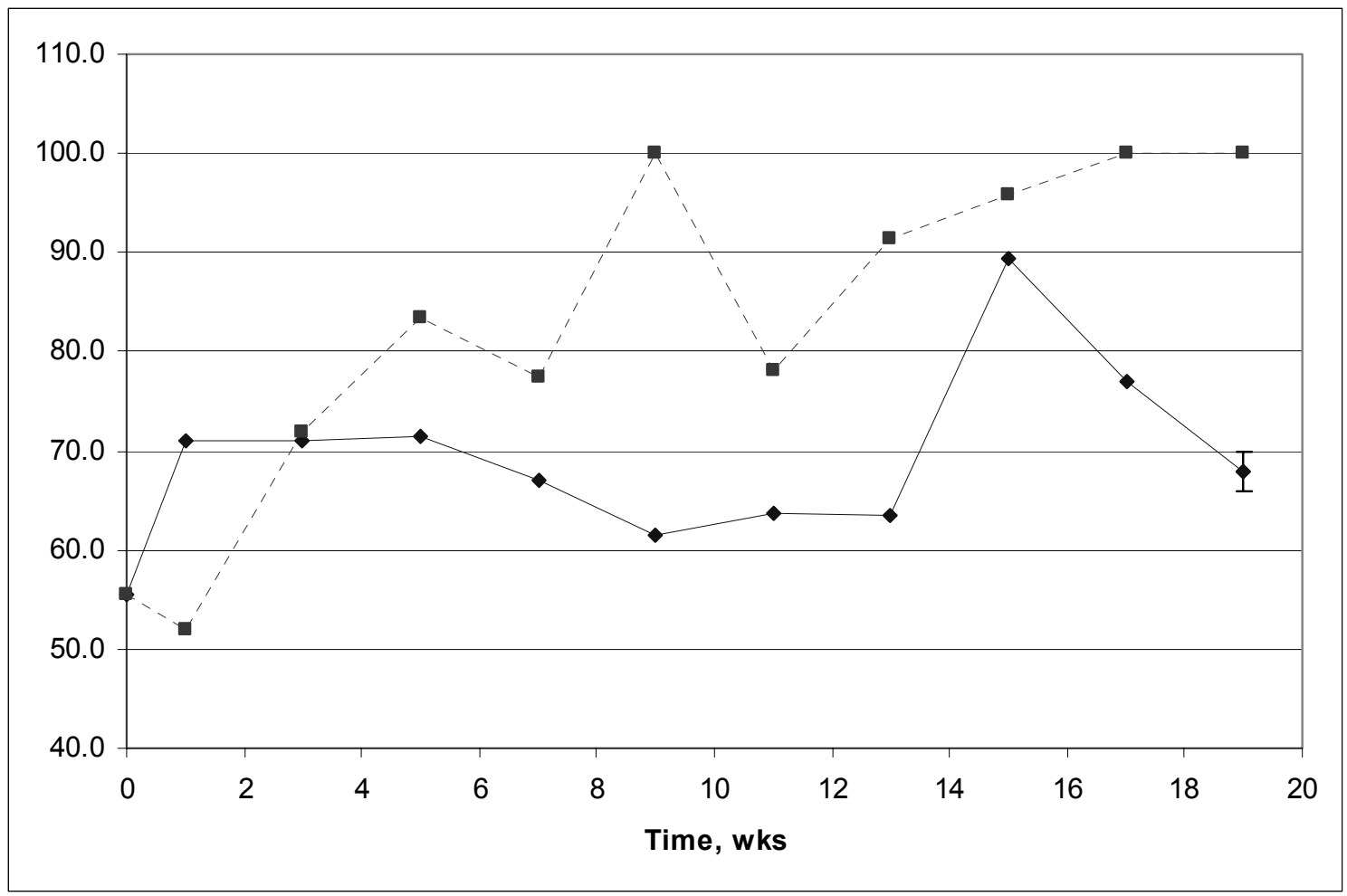

Figure 10. Blood HDL cholesterol concentration, $m g / d L$.

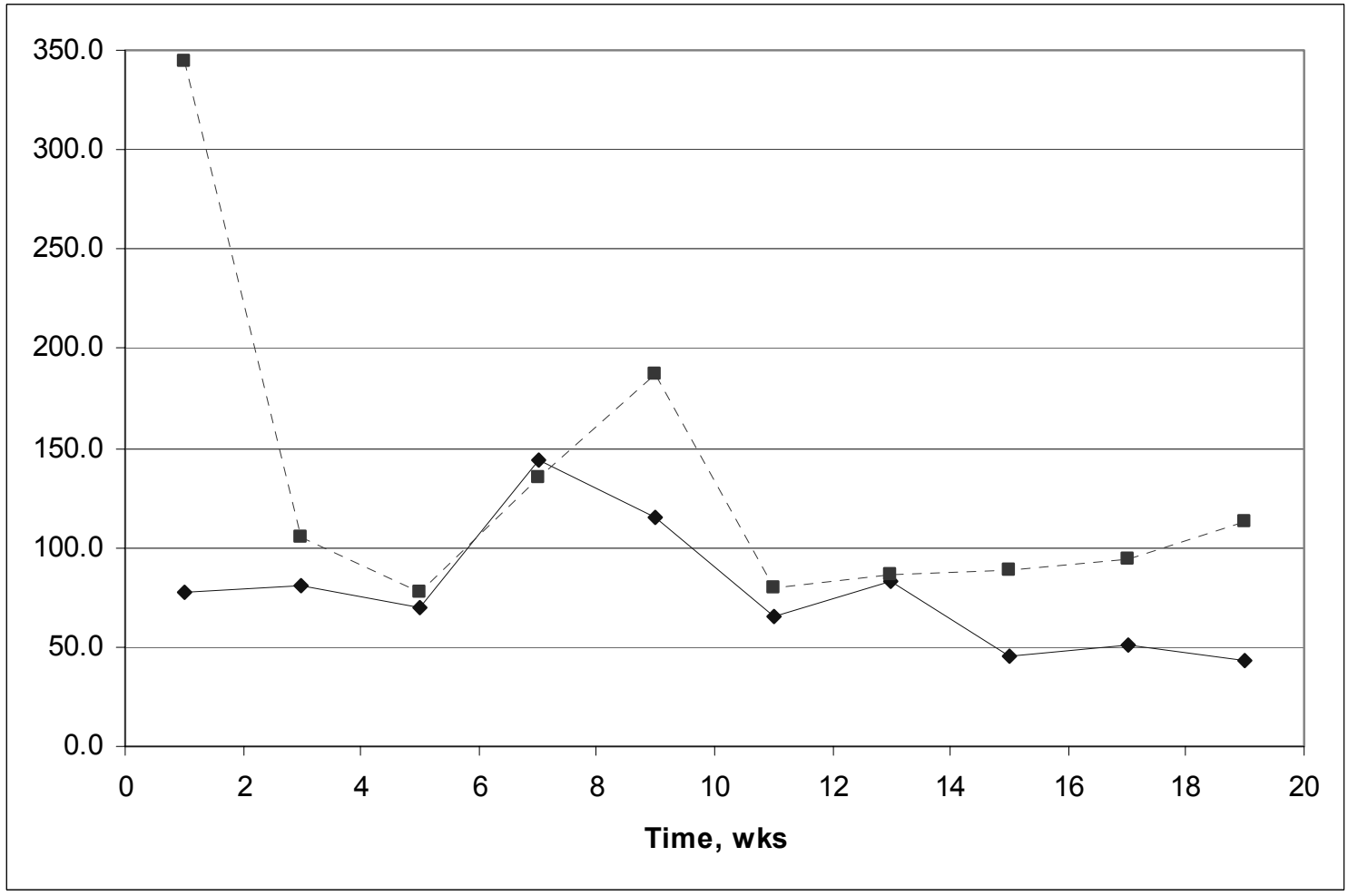

Figure 11. Plasma $\beta H B T$ concentration, $\mu M$. 


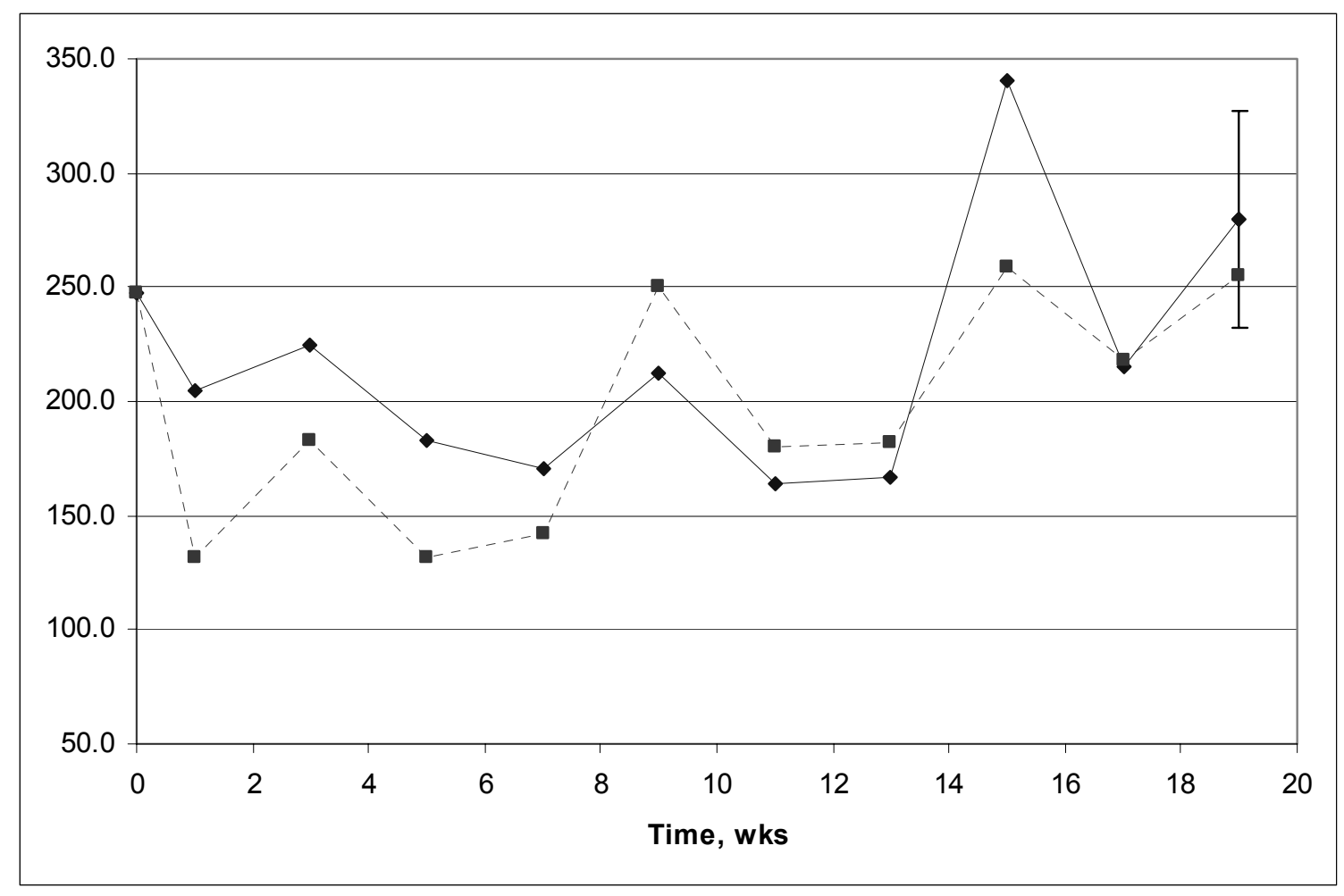

Figure 12. Blood glucose concentration, $m g / d L$.

regime did not produce weight loss, though ketosis was observed [37].

Metabolic and physiologic differences between humans and mice may account for the differential responses observed from LC-HFP diet adherence. In particular, the high relative liver weight of mice versus humans (approximately 5.0 vs. $2.5 \%$ of BW, respectively) [38] would have allowed for a relatively greater capacity for gluconeogenesis and glycogen storage in the mice than would be observed in humans. As such, glucose and glycogen depletion, and sustained ketosis may be demonstrated in humans on the type of diet examined here, allowing for the short-term weight loss demonstrated in human studies. Comparison of these results to dietary studies in murine subjects suggests the observed weight and fat gain was due primarily to the high fat content of the LC diet [22,24-26]. Reducing the protein content of the LC diet-to reduce the degree of gluconeogenesis from amino acid substrates-may have achieved normal weight and body composition, and should be considered as a factor in any future study. Additionally, as this study used relatively young, growing mice of normal initial weight, the efficacy of the LC diet as a weight loss regime was not determined; future research with adults from an obese strain would be necessary to achieve this end, though the findings of this study suggest that the LC diet used here would be an ineffective weight loss mechanism in mice.

\section{ACKNOWLEDGEMENTS}

Many thanks to Chris Bell and Misty Retzlaff for technical and analytical assistance; Drs. Mani Campos, Amy Olson, and Stephanie Toering for consultation; the CSB-SJU IACUC for project approval, facilities, and technical support; Drs. Stephan Stelzner and Richard White of the CSB-SJU Undergraduate Research and Honors Programs, respectively, for project approval and funding; and Drs. David Mitchell and Elizabeth Wurdak for all of their advise and assistance. 


\section{REFERENCES}

1. National Health and Nutrition Examination Survey. National Center for Health Statistics. http://www.cdc.gov/ nchs/nhanes.htm 3 Nov. 2004.

2. Newman, Cathy. Why are we so fat? Nat Geo. 2004, vol. 206, pp. 46-62.

3. Overweight and Obesity. US Centers for Disease Control and Prevention. 24 Jun. 2004. http://www.cdc.gov/nccdphp/ dnpa/ obesity/ 3 Nov. 2004.

4. Obesity. World Health Organization. 3 Sept. 2003. http://www.who.int/nut/ obs.htm 3 Nov. 2004.

5. Stern, L. et al. The Effects of LowCarbohydrate Versus Conventional Weight Loss Diets in Severely Obese Adults: One Year Follow-up of a Randomized Trial. Ann. Int. Med. 2004, vol. 140, No. 10; pp. 778-786. [PMID: 15148064]

6. Yancy, W. et al. A Low-Carbohydrate, Ketogenic Diet Versus a Low-Fat Diet to Treat Obesity and Hyperlipidemia. Ann. Int. Med. 2004, vol. 140, No. 10; pp. 769-779. [PMID: 15148063]

7. Astrup, A. et al. Atkins and Other LowCarbohydrate Diets: Hoax or an Effective Tool for Weight Loss? Lancet. 2004, vol. 364; pp. 897-899. [PMID: 15351198]

8. Westman, E. et al. Effect of 6-Month Adherence to a Very Low Carbohydrate Diet Program. Am. J. of Med. 2002, vol. 113; p.30-36. [PMID: 12106620]

9. Seshadri, P. et al. A Randomized Study Comparing the Effects of a LowCarbohydrate Diet and a Conventional Diet on Lipoprotein Subfractions and CReactive Protein Levels in Patients with Severe Obesity. Am. J. of Med. 2004, vol. 117; pp. 398-405. [PMID: 15380496]

10. Sondike, S. et al. Effects of a LowCarbohydrate Diet on Weight Loss and Cardiovascular Risk Factor in Overweight Adolescents. J. of Ped. 2003, vol. 142; pp. 253-258. [PMID: 12640371]

11. Foster, G. et al. A Randomized Trial of a Low-Carbohydrate Diet for Obesity. N. Eng. J. of Med. 2003, vol. 348; pp. 2082-2090. [PMID: 12761365]

12. Kappagoda, C. et al. LowCarbohydrate-High-Protein Diets: Is
There a Place for Them in Clinical Cardiology? J. of the Am. Col. of Card. 2004, vol. 43; pp. 725-730. [PMID: 14998607]

13. Atkins, R. Dr. Atkin's New Diet Revolution. New York: Avon, 2002.

14. Brody, T. Nutritional Biochemistry. San Diego: Academic Press, 1999.

15. Desmond, R. Warning on Atkins Diet. The Age. 15 March 2004. http://www.theage.com.au/index.html 24 March 2004.

16. Bravata, D. et al. Efficacy and Safety of Low-Carbohydrate Diets: A Systematic Review. J. of the Am. Med. Assoc. 2003, vol. 289; pp. 1837-1850. [PMID: 12684364]

17. Pestaña, A. and A. Sols. Reversible Inactivation of Rat Liver Serine Dehydratase by its Substrates. Febs. Lett. 1970, vol. 7; pp.29-31.

18. Johann, C. and Lentini E. Simultaneous Determination of Glycogen and Lipids from Heart Muscle. Anal. Biochem. 1971, vol. 43; pp. 183-187. [PMID: 5130397]

19. Peraino, C. Interactions of Diet and Cortisone in the Regulation of Adaptive Enzymes in Rat Liver. J. of Biol. Chem. 1967, vol. 242; pp. 3860-3867.

20. Bradford, M. A rapid and sensitive method for the quantitation of microgram quantities of protein utilizing the principle of protein dye binding. Anal. Biochem. 1971, vol. 72; pp. 248254. [PMID: 942051]

21. Garret, R. and C. Grisham. Biochemistry. $2^{\text {nd }}$ ed. Pacific Grove: Brooks-Cole, 1999.

22. Jean, C. et al. Metabolic Evidence for Adaptation to a High Protein Diet in Rats. J. of Nutr. 2002. 2002, vol. 131; p. 91-98.

23. Stipanuk, M. Biochemical and Physiological Aspects of Human Nutrition. Philadelphia: W.B. Saunders, 2000.

24. Peret, J. et al. Metabolic Effects of High-Protein Diets in Zucker Rats. Metab. 1984, vol. 33; p.200-207.

25. Gaíva, M. et al. Diets Rich in Polyunsaturated Fatty Acids: Effect on Hepatic Metabolism in Rats. Nutr. 2003, vol. 19; pp. 144-149. [PMID: 12591547] 
26. Diniz, Y. et al. Diets Rich in Saturated and Polyunsaturated Fatty Acids: Metabolic Shifting and Cardiac Health. Nutr. 2004, vol. 20; pp. 230-234.

27. National Research Council Subcommittee on Laboratory Animal Nutrition. Nutrient Requirements of Laboratory Animals. $4^{\text {th }}$ ed. Washington DC: National Academy of Sciences, 1995.

28. Morris, J. and C. Peraino. Immunochemical Studies of Serine Dehydratase and Ornithine Aminotransferase Regulation in Rat Liver in Vivo. J. of Bio. Chem. 1976, vol. 251; pp. 2571-2578. [PMID: 1262335]

29. Kanamoto, R. et al. Inverse Correlation Between the Nitrogen Balance and Induction of Rat Liver Serine Dehydratase (SDH) by Dietary Protein. Biosci., Biotech., and Biochem. 2004, vol. 68; pp. 888-893. [PMID: 15118319]

30. Eisenbach, L. et al. The Effect of Age on the Regulation of Glucose-6Phosphate Dehydrogenase in Mouse Liver. Exp. Geront. 1976, vol. 11; pp. 63-71. [PMID: 954878]

31. Stabile, L. et al. Postranscriptional Regulation of Glucose-6-Phosphate Dehydrogenase by Dietary Polyunsaturated Fat. Arch. of Biochem. and Biophys. 1996, vol. 332; pp. 269279. [PMID: 8806735]

32. Agius, L. et al. What Determines the Increase in Liver Cell Volume in the Fasted-to-Fed Transition: Glycogen or
Insulin? Biochem. J. 1991, vol. 276; pp. 843-845. [PMID: 2064620]

33. Hers, $H$. and L. Hue. Gluconeogenesis and Related Aspects of Glycolysis. Ann. Rev. Biochem. 1983, vol. 52; pp. 617-653. [PMID: 6311081]

34. Brehm, B. et al. A Randomized Trial Comparing a Very Low Carbohydrate Diet and a Calorie-Restricted Low Fat Diet on Body Weight and Cardiovascular Risk Factors in Healthy Women. J. of Clin. Endocr. \& Metab. 2003, vol. 88; pp. 1617-1623. [PMID: 12679447]

35. Phinney, S. et al. The Human Metabolic Response to Chronic Ketosis Without Caloric Restriction: Physical and Biochemical Adaptation. Metab. 1983, vol. 32; pp. 757-768. [PMID: 6865775]

36. Meckling, K. et al. Effects of a Hypocaloric, Low-Carbohydrate Diet on Weight Loss, Blood Lipids, Blood Pressure, Glucose Tolerance, and Body Composition in Free-Living Overweight Women. Can. J. Physiol. Pharmacol. 2002, vol. 80; pp. 1095-1105. [PMID: 12489929]

37. Sharman, M. et al. A Ketogenic Diet Favorably Affects Serum Biomarkers for Cardiovascular Disease in NormalWeight Men. J. Nutr. 2002, vol. 132; pp. 1879-1885.

38. Gray, H. The Liver. Anatomy of the Human Body. $20^{\text {th }}$ ed. Bartleby.com, 2000.

39. Purina TestDiet. Rat Diet 5012. St. Louis: Purina Mills LLC, 2002.

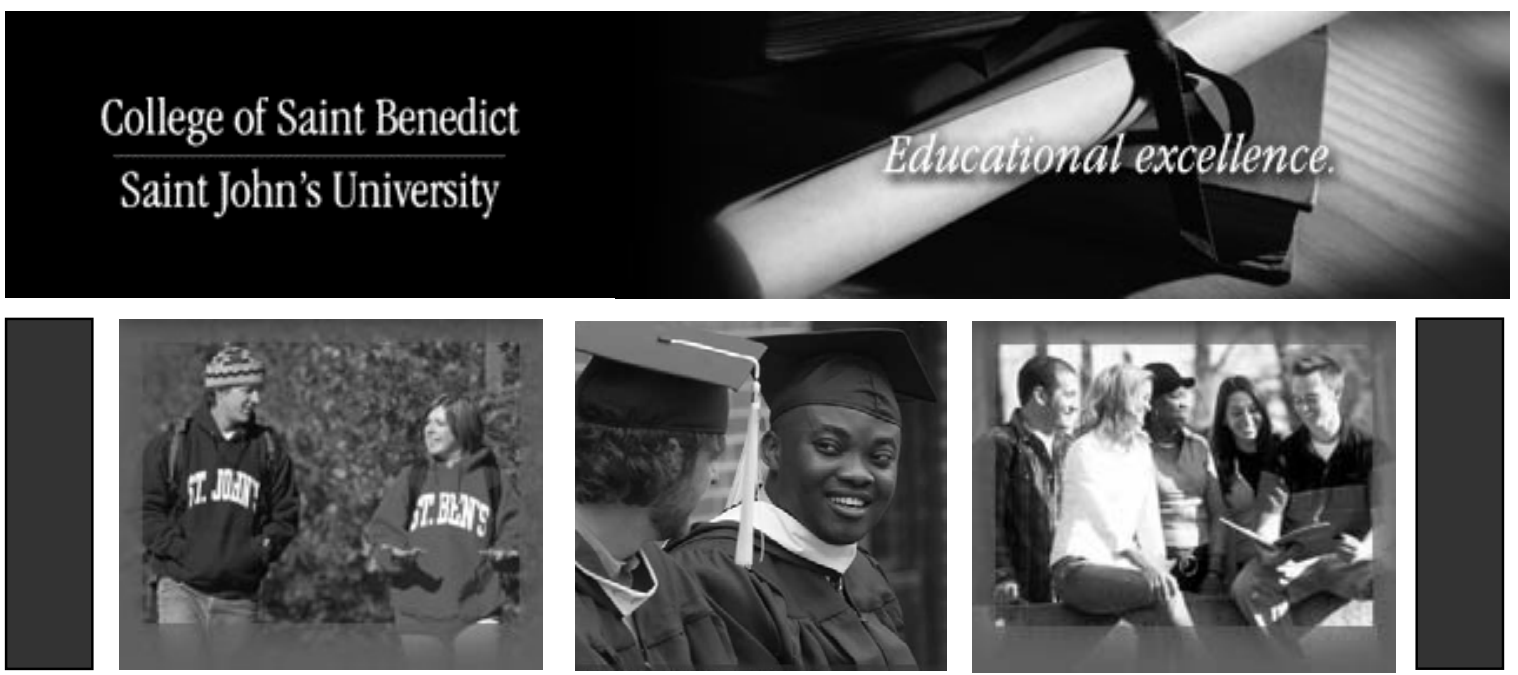




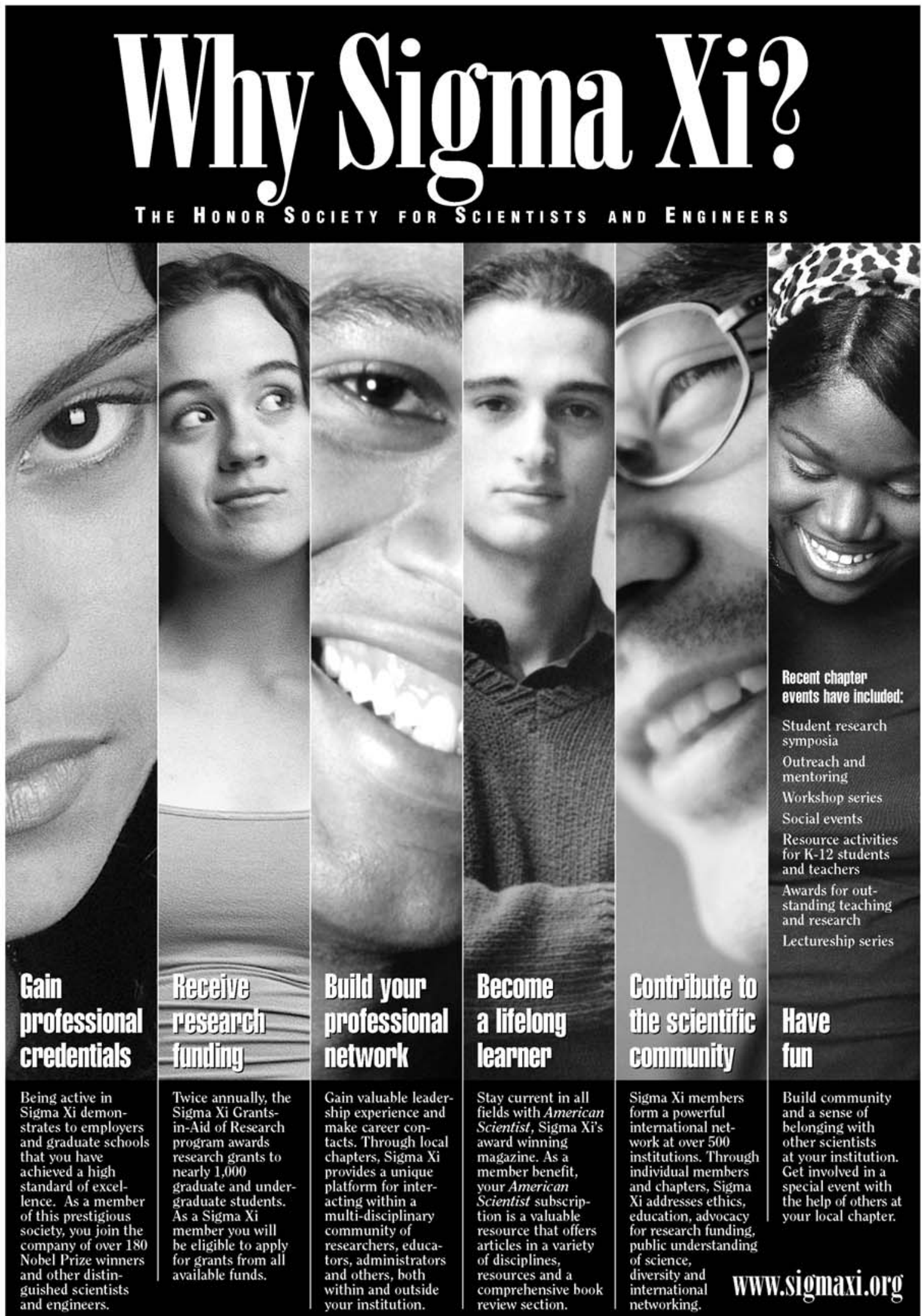

Sigma Xi, The Scientific Research Society • 89 Alexanter Drive • P.O. Box 13975 • Research Triangle Park, NC 27709 • 818-549-4681 • 800-243-6534 